\title{
HUBUNGAN MOTIVASI PERAWAT DENGAN KEPATUHAN PERAWAT DALAM PENERAPAN UNIVERSALPRECAUTION DI RSU RAJAWALI CITRA YOGYAKARTA
}

\author{
${ }^{1}$ Yunita Andika Mau, ${ }^{2}$ Agus Sarwo Prayogi \\ Prodi Ilmu Keperawatan Stikes Surya Global Yogyakarta \\ Jurusan Keperawatan Poltekkes Kemenkes Yogyakarta \\ saworbali@gmail.com
}

\begin{abstract}
Background: The nurse is the hospital's most frequent source of contact with the patient, so as to prevent nurses and patients from the risk of contracting nosocomial infections the need for nurse motivation to improve adherence in the application of universal precautions. Objective: To know the relationship between nurse motivation and nurse compliance in the application of universal precaution in Rajawali Citra Yogyakarta general hospital. Method: Type of research using descriptive quantitative with cross sectional approach. Number of samples of 45 nurses with total sampling technique. Data analysis using Chi-Square analysis. Results: The results showed that there was a correlation between nurse motivation and nurse compliance in the application of universal precaution at RSU Rajawali Citra Yogyakarta $p=0,000(\alpha 0,05)$ with correlation coefficient strength that is equal to 0,547 or medium relationship. Conclusion: There is a correlation between nurse motivation and nurse compliance in the application of universal precaution in RSU Rajawali Citra Yogyakarta with moderate relationship.
\end{abstract}

Keywords: motivation, compliance, nurse, Application of universal precaution.

\begin{abstract}
Abstrak
Perawat merupakan sumber daya di rumah sakit yang paling sering kontak dengan pasien, sehingga untuk mencegah perawat dan pasien dari resiko tertular penyakit infeksi nosocomial maka perlunya motivasi perawat untuk meningkatkan kepatuhan dalam penerapan universal precaution. Tujuan penelitian mengetahui hubungan antara motivasi perawat dengan kepatuhan perawat dalam penerapan universal precaution di rumah sakit umum Rajawali Citra. Metode: Jenis penelitian menggunakan desriptif kuantitatif dengan pendekatan cross sectional. Jumlah sampel 45 perawat dengan teknik total sampling. Analisis data menggunakan analisis Chi-Square. Hasil:Hasil penelitian menunjukkan bahwa ada hubungan antara motivasi perawat dengan kepatuhan perawat dalam penerapan universal precaution di RSU Rajawali Citra Yogyakarta $\mathrm{p}=0,000(\alpha 0,05)$ dengan kekuatan koefisiensi korelasi yaitu sebesar 0,547 atau hubungan sedang. Kesimpulan: Ada hubungan antara motivasi perawat dengan kepatuhan perawat dalam penerapan universal precaution di RSU Rajawali Citra Yogyakarta dengan keeratan hubungannya sedang.
\end{abstract}

Kata Kunci: motivasi, kepatuhan, perawat, Penerapan universal precaution.

\section{Pendahuluan}

Rumah sakit merupakan salah satu tempat pemberian pelayanan kesehatan kepada masyarakat terutama untuk masyarakat yang sedang sakit. Tujuan utama rumah sakit adalah memberikan pelayanan berkualitas demi tercapainya kepuasan pasien yang ditandai dengan berkurangnya keluhan dari pasien, sehingga menunjukan kinerja perusahaan yang tinggi. Pelayanan rumah sakit saat ini tidak saja bersifat kuratif (penyembuhan) tetapi juga 
pemulihan rehabilitatif). Oleh karena itu, harapan utama masyarakat datang ke rumah sakit adalah untuk mencapai keseimbangan dan kesehatan. (Juwita dalam Hayulita dan Pija, 2014). Tingginya angka kejadian infeksi nosokomial dapat menyebabkan turunnya kualitas mutu pelayanan medis, sehingga perlu adanya pencegahan dan penggendalian (Darmadi, 2008). Salah satu strategi yang sudah terbukti bermanfaat dalam upaya pengendalian infeksi nosokomial adalah dengan meningkatkan kemampuan petugas kesehatan dalam menjalankan metode universal precaution atau yang dalam istilah indonesia dikenal dengan kewasapadaan universal (Yulianti, dkk, 2011).

Kegiatan pencegahan penularan infeksi di rumah sakit melibatkan semua petugas kesehatan yang berada di lingkungan rumah sakit termasuk perawat. Perawat adalah petugas kesehatan yang paling sering berhubungan dengan pasien, sehingga dari semua petugas kesehatan perawatlah yang paling beresiko terpapar infeksi berbagai penyakit. Seperti pernyataan Efstathio yang di kuitp dalam Sahara (2011) mengatakan bahwa, secara global lebih dari tiga puluh lima juta petugas kesehatan beresiko terpajan infeksi penyakit dan setelah diobservasi diantara semua petugas kesehatan tersebut yang paling tinggi risiko terpajan infeksi adalah perawat.

Dasar universal precaution ini meliputi mencuci tangan guna mencegah infeksi silang, pemakaian alat pelindung diri diantaranya sarung tangan untuk mencegah kontak dengan darah serta cairan infeksius lain, pengelolaan alat kesehatan, pengelolaan jarum dan alat tajam untuk mencegah perlukaan, serta pengelolaan limbah (Depkes RI dalam Syahrizal, $\mathrm{dkk}, 2014)$. Dalam menggunakan prinsip universal precaution, petugas kesehatan memberi perlakukan yang sama pada semua pasien tanpa memandang penyakit atau diagnosanya, yaitu dengan asumsi bahwa setiap pasien memiliki resiko untuk menularkan penyakit yang berbahaya. Petugas harus memiliki pengetahuan yang baik tentang pencegahan transmisi infeksi, bersikap dan bertindak yang benar dalam melakukan setiap indakan. Hal ini sangat perlu di perhatikan karena setiap individu yang bekrja di lingkungan rumah sakit maupun pusat pelayanan kesehatan lainnya merupakan kelompok orang yang sangat rawan untuk tertular atau menularkan infeksi (Spiritia dalam Syahrizal, dkk, 2014).

Untuk melindungi perawat dan pasien dari resiko tertular penyakit infeksi tersebut maka dalam melaksanakan tindakan keperawatan, perawat harus selalu memperhatikan metode Universal Precaution (Kewaspadaan Universal) yang telah di tetapkan oleh Centers For Disease Control And Prevention (CDC) pada tahun 1988 di Amerika Serikat (Kirkland dalam Syahrizal, dkk, 2014). Menurut Kusmiyati (2009), faktor yang mempengaruhi rendahnya perilaku perawat dalam tindakan universal precautions yaitu : Pengetahuan, sikap, ketersediaan sarana alat pelindung diri dan motivasi perawat. Ketidak patuhan atau keengganan petugas untuk melakukan prosedur universal precautions adalah karena dianggap terlalu merepotkan dan tidak nyaman. Tugas perawat yang sangat banyak juga menjadi faktor lain menyebabkan perawat sulit untuk menerapkan universal precautions.

Berdasarkan hasil studi pendahuluan peneliti mengenai motivasi dengan kepatuhan perawat dalam penerapan universal precaution melalui wawancara ke 6 perawat yang bekerja di RSU Rajawali Citra pada bulan april 2016 didapatkan hasil bahwa dari ke 6 perawat menyatakan di RSU Rajawali Citra sudah menerapkan tentang universal precaution tetapi penggunaannya masih kurang di manfaatkan. Dan peneliti juga melakukan wawancara dengan salah satu perawat yang pernah lalai dalam hal penggunaan alat pelindung diri sehingga pasien di salah satu ruangan mengalami penyakit infeksi nosokomial dikarenakan kurang mengoptimalkan pelaksanaan dalam penerapan universal precaution. Tujuan penelitian Diketahui hubungan antara motivasi perawat dengan kepatuhan perawat dalam penerapan universal precaution. 


\section{Metode Penelitian}

Jenis penelitian Deskriptif kuantitatif dengan rancangan penelitian cross sectional. Populasi dalam penelitian ini adalah perawat yang berada di RSU Rajawali Citra Yogyakarta sebanyak 45 orang. Teknik sampel yang digunakan dalam penelitian ini adalah total sampling dengan Kriteria Inklusi 1) Perawat yang bekerja di RSU Rajawali Citra Yogyakarta; 2) Pendidikan Diploma III, Ners. Kriteria Ekslusi 1) Kepala ruangan; 2) Perawat yang cuti, penelitian dilakukan pada bulan November 2017

Motivasi perawat menggunakan kuesioner dari Diantari (2010) ini terdiri dari 19 item pernyataan dan pilihan jawaban yang tersedia menggunakan skala likert, dengan skala data data ordinal yaitu : Motivasi Tinggi : (76-100\%), Motivasi Sedang : (56- 75 \%), Motivasi Rendah : ( $<56 \%)$. Hasil uji validitas di Rumah Sakit Condong Catur dengan jumlah sampel sebesar 30 perawat yang bekerja di Rumah Sakit Condong Catur memiliki rhitung > rtabel $(0,361)$, validitas pada penelitian ini dilakukan pada tanggal 29 September sampai dengan 16 Oktober 2017, dan uji reabilitas instrument pada variabel bebas (motivasi perawat) memiliki $r$ cronbach alpha 0,939 . $r$ cronbach alpha $>0,7$, maka semua pernyataan pada variabel bebas (motivasi perawat) reliabel. Kepatuhan perawat menggunakan Kuesioner. Kuesioner ini penulis modifikasi dari Batseran (2014) ini terdiri dari 19 item pernyataan dan pilihan jawaban yang tersedia menggunakan skala guttman, skala data menjadi data nominal yaitu kategori patuh $(\geq 10)$ dan tidah patuh $(<10)$. Hasil uji validitas memiliki rhitung $>$ rtabel $(0,361)$ yang berarti valid, uji reabilitas memiliki $r$ cronbach alpha $0,968 . r$ cronbach alpha $>0,7$ maka semua pertanyaan pada variabel kepatuhan perawat reliabel. Pengujian hipotesis menggunakan analisa Chi Square

Hasil Penelitian

Adapun karakteristik perawat pada Rumah Sakit Umum Rajawali Citra Yogyakarta yang digunakan dalam penelitian ini adalah :

Tabel.1 Distribusi Frekuensi Responden berdasarkan jenis kelamin, usia, status perkawinan, pendidikan terakhir, lama kerja, status kepegawaian Di

Rumah Sakit Umum Rajawali Citra Yogyakarta

\begin{tabular}{|c|c|c|c|}
\hline \multirow{2}{*}{ Karakteristik } & \multirow{2}{*}{ Kategori } & \multicolumn{2}{|c|}{ Intervensi } \\
\hline & & frekuensi & persentase \\
\hline \multirow{2}{*}{ 1. Jenis kelamin } & Perempuan & 44 & 97,8 \\
\hline & Laki-laki & 1 & 2,2 \\
\hline \multirow[t]{2}{*}{ 2. Umur } & 21-30 tahun & 31 & 68,9 \\
\hline & 31-40 tahun & 14 & 31,1 \\
\hline \multirow[t]{2}{*}{ 3. Status perkawinan } & Menikah & 27 & 60,0 \\
\hline & Belum menikah & 18 & 40,0 \\
\hline \multirow[t]{2}{*}{ 4. Pendidikan terakhir } & DIII & 37 & 82,2 \\
\hline & SI Ners & 8 & 17,8 \\
\hline \multirow[t]{6}{*}{ 5. Lama kerja } & $<1$ tahun & 1 & 2,2 \\
\hline & 1 tahun & 4 & 8,9 \\
\hline & 2 tahun & 10 & 22,2 \\
\hline & 3 tahun & 9 & 20,0 \\
\hline & 4 tahun & 4 & 8,9 \\
\hline & $>5$ tahun & 17 & 37,8 \\
\hline \multirow{2}{*}{ 6. Status kepegawaian } & Tetap & 35 & 77,8 \\
\hline & Kontrak & 10 & 22,2 \\
\hline
\end{tabular}


Tabel.2 Distribusi Frekuensi Motivasi Perawat

Di RSU Rajawali Citra Yogyakarta

\begin{tabular}{|c|c|c|c|}
\hline & \multirow{2}{*}{ Kategori } & \multicolumn{2}{|c|}{ Intervensi } \\
\hline & & frekuensi & persentase \\
\hline & Tinggi & 23 & 51,1 \\
\hline & Sedang & 20 & 44,4 \\
\hline & Rendah & 2 & 4,4 \\
\hline & Jumlah & 45 & 100 \\
\hline
\end{tabular}

merupakan suatu bentuk dorongan yang timbul dari dalam diri perawat yang bekerja di Rumah Saki Umum Rajawali Citra Yogyakarta ataupun mendapat dorongan dari orang lain yang dapat meningkatkan kegairahan kerja perawat yang bekerja di Rumah Sakit Umum Rajawali Citra Yogyakarta. Berdasarkan tabel.2 menunjukan bahwa (51,1) responden memiliki motivasi tinggi

Tabel .3 Distribusi Frekuensi Kepatuhan Perawat

Di RSU Rajawali Citra Yogyakarta

\begin{tabular}{ccc}
\hline \multirow{2}{*}{ Kategori } & \multicolumn{2}{c}{ Intervensi } \\
\cline { 2 - 3 } & frekuensi & persentase \\
\hline Patuh & 28 & 62,2 \\
Tidak patuh & 17 & 37,8 \\
\hline Jumlah & 45 & 100 \\
\hline
\end{tabular}

Kepatuhan Perawat merupakan ketaatan perawat yang bekerja di Rumah Sakit Umum Rajawali Citra Yogyakarta sebagai tenaga profesional terhadap suatu anjuran, dan peraturan yang harus ditaati dalam melaksanakan penerapan universal precaution. Berdasarkan tabel. 3 menunjukan bahwa $(62,2)$ perawat yang patuh.

Tabel .4 Tabulasi silang dan analiss Chi Square Motivasi Perawat Dengan Kepatuhan Perawat Dalam Penerapan Universal Precaution Di Rumah Sakit Umum Rajawali Citra Yogyakarta

\begin{tabular}{|c|c|c|c|c|c|c|c|}
\hline & & \multicolumn{4}{|c|}{$\begin{array}{c}\text { Kepatuhan Perawat dalam } \\
\text { penerapan universal precaution }\end{array}$} & \multirow{3}{*}{$\begin{array}{c}\text { Nilai } \\
\mathbf{P}\end{array}$} & \multirow{2}{*}{$\begin{array}{l}\text { Nilai } \\
\mathbf{r}\end{array}$} \\
\hline & & \multicolumn{2}{|c|}{ Patuh } & \multicolumn{2}{|c|}{ Tidak patuh } & & \\
\hline & & frekuensi & persentase & frekuensi & persentase & & \\
\hline Motivasi & Tinggi & 22 & 48,9 & 1 & 2,2 & & \\
\hline \multirow[t]{3}{*}{ Perawat } & Sedang & 4 & 8,9 & 16 & 35,6 & 0,000 & 0,547 \\
\hline & Rendah & 2 & 4,4 & 0 & 0 & & \\
\hline & & 28 & 62,2 & 17 & 37,8 & & \\
\hline
\end{tabular}

Berdasarkan tabulasi silang antara motivasi perawat dengan kepatuhan perawat dalam penerapan universal precaution pada tabel 4.4 menunjukkan bahwa responden dengan motivasi perawat tinggi melakukan penerapan universal precaution kategori patuh sebanyak 22 orang $(48,9)$. Hasil uji chi- square menunjukkan nilai $\mathrm{p}=0,000(<0,05)$ karena nilai $\mathrm{p}<$ 0,05 maka dapat disimpulkan terdapat hubungan antara motivasi perawat dengan kepatuhan perawat. Nilai koefisien korelasi (r) menunjukkan 0,547 terdapat hubungan dengan kekuatan sedang. 


\section{Pembahasan}

Hasil penelitian ini menunjukkan bahwa mayoritas perawat memiliki tingkat motivasi perawat dalam kategori tinggi. Dimana hal ini didukung oleh penelitian yang dilakukan oleh Hayulita dan Paija (2014) diperoleh hasil bahwa tingkat motivasi perawat yang sebagaian besar dalam kategori tinggi. Motif atau motivasi berasal dari kata Latin " moreve" yang berarti dorongan dari dalam diri manusia untuk bertindak atau berperilaku. Pengertian motivasi tidak terlepas dari kata kebutuhan atau "needs" atau "want". Kebutuhan adalah suatu "potensi" dalam diri manusia yang perlu ditanggapi atau direspon. Motivasi berasal dari dalam diri maupun dari luar diri individu, motivasi yang berasal dari dalam diri misalnya seperti yang sudah dijelaskan sebelumnya bahwa responden takut tertular penyakit dari pasien yang dirawatnya dan menjaga kebersihan dirinya, sedangkan motivasi yang berasal dari luar diri responden misalnya adanya ketentuan dari lahan pekerjaan yang harus memakai alat pelindung diri dalam melakukan tindakan dan berbagai pelatihan yang dilakukuan tentang pencegahan infeksi nosokomial dan proteksi diri (Hayulita dan Paija, 2014).

Menurut penelitian tingginya motivasi perawat dalam penerapan universal precaution itu karena pada umumnya perawat sudah mengetahui tentang dampak dari universal precaution itu sehingga untuk menghindari infeksi nosokomial tersebut diharapkan untuk selalu mencuci tangan guna mencegah infeksi silang, pemakaian alat pelindung diri di antaranya sarung tangan untuk mencegah kontak dengan darah serta cairan infeksius lain, pengelolaan alat kesehatan, pengelolaan jarum dan alat tajam untuk mencgah perlukaan, serta pengelolaan limbah (Depkes RI, 2009), hal tersebut bisa menimbulkan motivasi yang tinggi bagi perawat.

Tanggung jawab merupakan prinsip dasar dibelakang pengembangan kinerja. Dengan memahami dan menerima tanggung jawab atas apa yang mereka kerjakan dan tidak kerjakan untuk mencapai tujuan mereka (Wibowo, 2013). Asumsi peneliti jika tanggung jawab yang diterima oleh perawat, tentu yang sesuai dengan kapasitasnya telah mendorong motivasi perawat untuk menjalankannya dengan sebaik mungkin. Selain itu hal yang dapat mempertahankan motivasi seseorang adalah adanya perasaan di berdayakan sehingga dapat berkarya dengan sepenuh hati artinya mereka dapat memberikan kontribusi sesuai kompetensi masing-massing.

Hasil penelitian didapatkan hasil bahwa kepatuhan perawat dalam penerapan universal precaution yang dalam kategori patuh (62,2\%) Artinya perawat yang bekerja di Rumah Sakit Umum Rajawali Citra Yogyakarta sebagian besar sudah patuh dalam melaksanakan penerapan universal precaution. Hasil penelitian ini sejalan dengan Nurkhasanah \& Sujianto (2013), yang menyatakan sebagian besar responden patuh. Menurut Nurkhasanah \& Sujianto (2013 Kepatuhan perawat adalah perilaku perawat sebagai seorang yang profesional terhadap suatu anjuran, prosedur atau peraturan yang harus dilakukan atau ditaati. Kepatuhan perawat dalan penerapan kewaspadaan universal sesuai prosedur tetap yang telah ditetapkan (Weston, 2008).

Menurut Siagian (1995), pendidikan akan mempengaruhi seseorang dalam mengambil keputusan sehingga semakin tinggi tingkat pendidikan seseorang semakin mengerti dan memahami tentang sesuatu ilmu serta akan berpengaruh pada perilakunya, sehingga perilaku kepatuhannya akan lebih tinggi. Menurut penelitian Indrianingsih (2005) bahwa pendidikan akan mempengaruhi seseorang dalam berpikir dan dalam mengambil suatu keputusan. Diperkuat lagi oleh Hughes (2008) yang mengatakan bahwa tingkat pendidikan merupakan salah satu karakteristik individu yang dapat meningkatkan pengetahuan perawat untuk dapat menerapkan universal precaution, sehingga dapat menurunkan angka kejadian tidak diharapkan.

Latar belakang pendidikan mempengaruhi kepatuhan perawat dalam penerapan universal precaution (Anugrahini, Sahar, Mustikasari, 2010). Faktor yang mempengaruhi 
kepatuhan perawat dapat dikategorikan menjadi faktor internal yaitu karakteristik yang dimiliki oleh perawat itu sendiri, misal sikap merupakan penentu dari perilaku karena keduanya berhubungan dengan persepsi, kepribadian, perasaan dan motivasi. Sikap merupakan keadaan mental yang dipelajari dan diorganisasikan melalui pengalaman, menghasilkan pengaruh spesifik pada responden seseorang terhadap orang lain, objek, situasi yang berhubungan. Sikap menentukan pandangan awal seseorang terhadap pekerjaan dan tingkat kesesuaian antara individu dengan organisasi (Ivancevich et al dalam K \& Anjarsari 2012). Selain itu motivasi juga mempengaruhi kepatuhan. Jika seseorang mempunyai motivasi untuk mempertahankan perilaku sesuai prosedur, maka kepatuhan akan meningkat. Faktor eksternal yaitu karakteristik yang dimiliki dari luar diri perawat, misal karakteristik organisasi, karakteristik kelompok, karakteristik pekerjaan, dan karakteristik lingkungan. Untuk meningkatkan kepatuhan sebaiknya seseorang tersebut mempunyai sikap dalam hal kepribadian yang baik serta motivasi yang besar dalam menjalankan kepatuhan perawat dalam penerapan universal precaution.

Berdasarkan hasil penelitian perawat menunjukan bahwa terdapat hubungan motivasi perawat dengan kepatuhan perawat dalam penerapan universal precaution di Rumah Sakit Umum Rajawali Citra Yogyakarta, sehingga dapat disimpulkan bahwa semakin tinggi motivasi perawat maka kepatuhan perawat akan mengalami peningkatan atau semakin patuh, begitupula sebaliknya semakin berkurang motivasi perawat maka semakin rendah pula kepatuhan perawat yang dimiliki perawat yang bekerja di Rumah Sakit Umum Rajawali Citra Yogyakarta. Hasil penelitian ini sejalan dengan penelitian yang dilakukan Chrysmadani (2011) tentang analisis faktor yang berhubungan dengan kepatuhan perawat dalam penggunaan alat pelindung diri dasar (handscoon dan masker) di Rumah Sakit Graha Husada Gresik yang menyimpulkan bahwa sebagian besar responden adalah bermotivasi baik, dan tidak satupun bermotivasi kurang dalam pemakain APD dasar.

Selain itu, penelitian lain dari Tawale, Budi dan Nurcholis (2011) didapatkan hasil adanya hubungan yang negatif antara motivasi dengan kecenderungan mengalami burnout pada perawat. Penelitian Larasati, Gilang dalam Jamila, 2016) diperoleh hasil adanya hubungan antara motivasi dan kinerja pegawai. Penelitian Ngatemin dan Arumwati (2012) didapatkan hasil adanya hubungan yang positif antara kompetensi dan kompensasi dengan motivasi dari karyawan. Sejalan dengan penelitian yang dilakukan oleh Umar dalam Triyono (2012) serta teori dua faktor Herzberg mengatakan bahwa faktor yang mempengaruhi seorang individu akan termotivasi atau tidaknya adalah faktor intrinsik dan ekstrinsik. Faktor intrinsik motivasi (faktor motivasi) berupa prestasi, pengakuan, pekerjaan itu sendiri, tanggung jawab, dan pengembangan potensi individu, sedangkan faktor ekstrinsik (faktor pemeliharaan) rupa gaji, kondisi kerja, kebijakan dan administrasi perusahaan, hubungan antar pribadi dan kualitas supervisi.

Menurut Tawale, Budi dan Nurcholis (2011) dalam penelitiannya mengatakan bahwa motivasi sangat diperlukan dalam dunia keperawatan. Sejalan dengan hasil penelitian yang diutarakan oleh Makta,dkk dalam Jamila, 2016) bahwa motivasi pada perawat sangat berdampak pada kinerja yang dihasilkannya. Motivasi yang rendah dapat disebabkan oleh banyak faktor, diantaranya adalah beban kerja, kompetensi dan kompensasi yang diberikan (Ngatemin dan Arumwati, 2012). Motivasi yang rendah dapat mengakibatkan seringnya perawat izin meninggalkan kerja, pekerjaan akan tertunda, hasil pekerjaan tidak memuaskan, komunikasi jadi buruk dan berdampak pila pada pelayanan perawatan profesional terhadap masyarakat (Widyastuti dalam Jamila 2016). Hal ini semua mencerminkan dari rendahnya produktivitas kerja seorang perawat.

Kepatuhan adalah suatu perilaku manusia yang taat terhadap aturan, perintah, prosedur, dan disiplin. Perilaku kepatuhan bersifat sementara karena ini akan bertahan ada pengawasan, jika pengawasan hilang atau mengendur maka akan timbul perilaku 
ketidakpatuhan. Perilaku kepatuhan ini akan optimal jika perawat itu sendiri menggaggap perilaku ini bernilai positif yang akan diintegrasikan melalui tindakan asuhan keperawatan. Perilaku keperawatan ini akan dapat dicapai jika manajer keperawatan merupakan orang yang dapat dipercaya dan dapat memberikan motivasi (Sarwono, 2007). Faktor yang mempengaruhi kepatuhan perawat dapat dikategorikan menjadi faktor internal yaitu karakteristik yang dimiliki oleh perawat itu sendiri. Misal kepribadian. Kepribadian adalah organisasi dinamis dari sistem-sistem psikofisik dalam individu yang turut menentukan caracaranya yang unik atau khas dalam menyesuaikan diri dengan lingkungan jika kepribadian itu baik terhadapkeluarga maka akan baik pula terhadap orang lain. Selain itu motivasi juga mempengaruhi kepatuhan.

Jika seseorang mempunyai motivasi untuk mempertahankan perilaku yang sesuai prosedur, maka kepatuhan akan meningkat. Faktor eksternal yaitu karakteristik yang dimilki dari luar diri perawat, misal karakteristik organisasi, kelompok, pekerjaan, dan lingkungan. Untuk meningkatkan kepatuhan sebaiknya seseorang tersebut mempunyai kepribadian yang baik serta motivasi yang besar dalam menjalankan penerapan universal precaution, karena motivasi perawat dapat meningkatkan motivasi dalam dirinya dengan cara menyadari dan memahami bahwa pekerjaan yang ia jalani adalah tugas yang mulia serta dapat pula diperoleh dari pemimpinnya yang dengan berbagai upaya untuk memotivasinya dalam bekerja. Motivasi adalah pemberi daya penggerak yang menciptakan kegairahan kerja seseorang, agar mau bekerja sama, bekerja efektif dan terintegerasi dengan segala daya upayanya untuk mencapai kepuasan. (Malayu dalam Hayulita dan Paija, 2014). Motivasi berasal dari dalam diri maupun dari luar diri individu, motivasi yang berasal dari dalam diri misalnya seperti yang sudah dijelaskan sebelumnya bahwa responden takut tertular penyakit dari pasien yang dirawatnya dan menjaga kebersihan dirinya, sedangkan motivasi yang berasal dari luar diri responden misalnya adanya ketentuan dari lahan pekerjaan yang harus memakai alat pelindung diri dalam melakukan tindakan dan berbagai pelatihan yang dilakukuan tentang pencegahan infeksi nosokomial dan proteksi diri (Hayulita dan Paija, 2014). Mengembangkan dan mengaplikasikan motivasi dengan berbagai macam jenisnya baik yang bersifat intrinsik maupun ekstrinsik untuk meningkatkan kepatuhan perawat dalam penerapan universal precaution

\section{Kesimpulan}

Motivasi kerja perawat tidak boleh disepelekan atau diabaikan tanpa diperhatikan, karena motivasi merupakan salah satu faktor yang memiliki kontribusi dalam meningkatkan kepatuhan perawat dalam memberikan pelayanan kesehatan yang optimal pada masyarakat. Hubungan antara motivaasi dengan kepatuhan perawat dalam penerapan universal precaution di RSU Rajawali Citra, yang dibuktikan dengan nilai korelasi chi square 0,547 dengan nilai $\mathrm{p}$ $<0,05$.

\section{Daftar Pustaka}

Anugrahini, Sahar, Mustikasari, (2010). Kepatuhan Perawat Menerapkan Pedoman Patient Safety Berdasarkan Faktor Individu dan Organisasi. JKI Vol 13, No 3 November (2010) http://jki.ui.ac.id/index.php/jki/article/view/244

Darmadi. 2008. Infeksi Nosokomial Problematika dan Pengendaliannya. Jakarta : Salemba Medika.

Depkes. 2009. Pedoman pelaksanaan Kewaspadaan Universal di Pelayanan Kesehatan. Jakarta http://mewaspadai-infeksi nosokomial.html/2012/10/ di dilihat 24 mei 2016 
Hayulita \& Paija. 2014. Hubungan motivasi dengan penggunaan alat pelindung diri oleh perawat pelaksana di ruang rawat inap rsi ibnu sina bukittinggi tahun 2014. http://ejournal.stikesyarsi.ac.id/index.php/JAV1N1/article/viewFile/17/143

Hughes, G.H. (2008). Patient safety and quality: An evidence based handbook for nurse. Diperoleh dari http://www.proquest.com.

Indrianingsih (2005) Faktor-Faktor Yang Berhubungan Dengan Perilaku Kepatuhan Perawat Dalam Pencegahan Infeksi Luka Operasi Di Ruang Rawat Inap Rsud Dr. Moewardi Surakarta

Ivancevich, John M. 2007. Human Resource Management. New York: Mc Graw- Hill.

Kusmiyati. 2009. Faktor-faktor yang Mempengaruhi Penggunaan Alat Pelindung, diri dilihat 23 desember 2017 http://digilib.unimus.ac.id/files/disk1/134/jtptunimus-gdl gunawannim - 6663-2-babi.pdf

Ngatemin \& Arumwati, W 2012, Pengaruh Kompetensi Dan Kompensasi Terhadap Motivasi Kerja Karyawan Hotel di Kabupaten Karo Provinsi Sumatera Utara' Jurnal Riset Akuntansi Dan Bisnis, Vol. 12, No. 2, dilihat 23 desember 2017, http://library.unimed.ac.id/.

Nurkhasanah \& Sujianto, (2013). Kepatuhan Perawat Dalam Penerapan Kewaspadaan Universal Di Rumah Sakit Dokter Kariadi Semarang Tahun 2013. Prosiding Konferensi Nasional II Ppni Jawa Tengah 2014. https://jurnal.unimus.ac.id/index.php/psn12012010/article/view/1146/1200

Siagian, P. Sondang. 2006. Manajemen Sumber Daya Manusia.jakarta: Bumi Aksara

Sahara, A. 2011. Faktor-faktor yang Berhubbungan dengan Kepatuhan Perawat dan Bidan dalam Penerapan Kewaspadaan Universal. (http://www.ebookspdf. orgayusahara) dilihat 30 mei 2016.

Tawale, Budi \& Nurcholis. 2011. Hubungan Antara Motivasi Kerja Perawat Dengan Kecenderungan Mengalami Burnout Pada Perawat Di RSUD Serui-Papua. Fakultas Psikologi Universitas Hang-Tuah Surabaya. INSAN Vol. 13 No. 02, Agustus 2011. http://journal.unair.ac.id/filerPDF/2-13_2.pdf

Weston, Debbie, 2008, Infection Prevention and Control : Theory and Clinical Practice for Healthcare Professionals,England John Wiley \& Sons, Ltd

Wibowo, 2013. Manajemen kinerja. Cetakan keenam. Jakarta. Rajawali Pers.

Widyastuti, M 2013, Analisa Faktor-Faktor Yang Mempengaruhi Motivasi Kerrja Perawat Pelaksana Di RS Premier Surabaya, dilihat 23 desember 2017, http://stikeshangtuah.sby.ac.id.

Yulianti, Rosyidah, Widodo, H 2011, Hubungan Tingkat Pengetahuan Perawat Dengan Penerapan Universal Precaution Pada Perawat Di Bangsal Rawat Inap Rumah Sakit PKU Muhammadiyah Yogyakarta, dilihat 23 desember 2017, http://jogjapress.com/index.php/KesMas/article/view/1199/615 